\title{
Complaint Behaviour between Generations and Its Transmissions: An Exploratory Study in Malaysia
}

\author{
Hiram Ting ${ }^{1}$, Winnie Poh-Ming Wong ${ }^{2}$ \& Ernest Cyril de Run ${ }^{3}$ \\ ${ }^{1}$ Institute of Borneo Studies, Universiti Malaysia Sarawak, Sarawak, Malaysia \\ ${ }^{2}$ School of Business and Management, University College of Technology Sarawak, Sarawak, Malaysia \\ ${ }^{3}$ Faculty of Economics and Business, Universiti Malaysia Sarawak, Sarawak, Malaysia \\ Correspondence: Hiram Ting, Institute of Borneo Studies, Universiti Malaysia Sarawak, 94300, Kota Samarahan, \\ Malaysia. Tel: 601-6870-3412. E-mail: hiramparousia@gmail.com
}

Received: September 18, 2016

doi:10.5539/ijbm.v11n11p279
Accepted: October 9, 2016 Online Published: October 27, 2016

URL: http://dx.doi.org/10.5539/ijbm.v11n11p279

\begin{abstract}
Despite the abundance of marketing literature on consumer complaint behaviour, little is done to explicate such behaviour from generational perspectives. How the older and younger groups complain, and whether the latter learn or inherit behavioural values from the former remain unknown. Using theories pertinent to complaint behaviour and social learning theory as the basis, the present study aims to look into complaint behaviour between two generations, namely the mothers and the daughters. A qualitative approach using dyad interview was employed in Malaysia to gain insights not only about their respective complaint behaviour but also its similarities and differences simultaneously. Subsequently, five pairs of mothers and daughters were interviewed. All interviews were transcribed and analyzed using content analysis. The findings show that while the mothers would most likely seek redress in person, complain to others verbally and take no action, the daughters tend to seek redress and tell others about it using electronic media. There is apparent similarity in seeking redress and ranting on between the mothers and daughters but the younger generation tends to do it via social media. The study thus serves as a precursor to future investigation on complaint behaviour by different generation cohorts in the same family and the potential transmission of behavioural values between them. Practical implications are provided.
\end{abstract}

Keywords: complaint behaviour, dyad interview, generation, transmission, qualitative

\section{Introduction}

Consumers become dissatisfied when the products (including goods and services) they purchase or use do not meet their expectations. However, the manners of which the consumers react due to dissatisfaction differ from one person to another (Metehan \& Yasemin, 2011). Some would seek redress from the sellers in person, some choose to avoid any confrontation, and some would rant on to tell others about the product and the company (Mellor, Martin, \& Bradley, 2014). All these reactions are related to complaint behaviour which is a process where consumers evaluate their dissatisfaction after purchasing the products. It is generally concluded that consumers can get upset relatively easy due to the quality and price of the product and the manner the service is purveyed (Carnoy, 2015).

While consumer complaint behaviour (CCB) is a well-studied topic in marketing literature, little is known whether such behaviour is different by generations and whether it is transmittable between two generations. Such consideration is necessary because many consumers today still purchase the products with their family members and make purchase or post-purchase decisions jointly. If the parents are unhappy with certain products or services, their negative responses would likely affect their children to a certain degree. In fact, generational transmission between the parents and the children has been looked into in past studies (Cipriani, Giuliano, \& Jeanne, 2007; Hoge, Petrillo, \& Smith, 1982; Barni, Ranieri, Scabini, \& Rosnati, 2011), and it is something well-established in biological and anthropological research. Nevertheless, generational transmission is relatively less researched in consumer behaviour, let alone complaint behaviour. It is assumed that children's patterns of behaviour are learnt through direct experience and by observing the behaviours of their parents (Bandura, 1971). 
While it is known that behavioural values can be shared across generations (De Run \& Ting, 2013), there is no evidence to date to substantiate the transmission of complaint behaviour between generations.

In the Malaysian scenario, the cases of consumer complaint happen frequently, and the manners of complaint differ from one case to another. For instance, a consumer decided to complain about a MAGGI noodles cup and make it public in order to generate awareness about the incident (Singh, 2015). However, Malaysians are found to be more likely complaining privately to their family and friends, rather than confronting the persons who facilitate the purchasing process (Malhotra, Oly-Ndubisi, \& Agarwal, 2008). It corresponds to past studies that Malaysians are highly collectivistic (Hofstede \& Bond, 1988), thus they are more sensitive towards others' perceptions. As a result, they are more inclined to cringe away than people from individualist societies. This might explain why Malaysians prefer not to complain publicly about their dissatisfaction because such behaviour is perceived to have negative effect on their self-image (Singelis \& Sharkey, 1995). Whether these findings still hold true in contemporary setting remains largely uncertain.

There seems to be contradiction between how cases of complaint have recently transpired and how CCB is documented in literature pertaining to Malaysian consumers. Moreover, in spite of the implication of generational differences and generational transmission between the parents and the children in biological sense, there is an extreme lack of literature that articulates complaint behaviour by generations and the reasons to behaving in such manners. Furthermore, in light of the competitive business environment, consumers often make purchase decision with reference to others, especially their family members. Inevitably, there will always be someone will always voice out their displeasure about something despite the effort from the business personnel to satisfy them and rectify the problems. Hence, the lack of understanding about complaint behaviour by generations could hinder the business from serving consumers from different age groups effectively and persistently. Therefore, this study aims to explore CCB between two generations, namely the mothers and the daughters in Malaysia using qualitative approach. Dyad interview is appropriated so as to provide a clear understanding of the similarities and differences of complaints between them, and whether transmission takes places. It is believed that such attempt would extend knowledge about CCB and provide practical understanding not only about the similarities and differences between generations, but also the transmission from one to another.

\section{Literature Review}

\subsection{Consumer Complaint Behaviour by Generations}

$\mathrm{CCB}$ contains numerous behavioural and non-behavioural responses towards product failures (Kruger \& Mostert, 2014). When consumers are dissatisfied with the products that they purchase or consume, they would take series of reactions either in the form of verbal or non-verbal conducts (Tronvoll, 2011). Hence, CCB includes all probable responses of dissatisfaction related to the purchase, consumption or possession of products (Vincent \& Webster, 2005). As such, it is largely described as a process that occurs when the consumers' experience lies outside the acceptance zone in the process of evaluating the products based on their expectation. It encompasses complex combination of psychological and behavioural factors (Kang, Zhang, \& Zheng, 2009).

Notwithstanding abundance of literature on $\mathrm{CCB}$ using various behavioural constructs in diverse situations (Broadbridge \& Marshall, 1995; Kim, Im, \& Shin, 2003; Kruger \& Mostert, 2014; Nimako, 2014), and some evidence in the Malaysian context (Malhotra, Oly-Ndubisi, \& Agarwal, 2008; Mat, Said, Bakar, Munir, \& Kori, 2014; Ndubisi \& Tam, 2007), there is no mentioning of complaint behaviour by generations. Past studies have briefly shown the older generation tends to complain less than the younger groups who are likely to take some form of action to express their dissatisfaction (Mahayudin, Haron, \& Chan, 2010; Ngai, Heung, \& Chan, 2007). It is also asserted that due to the experiences of the older consumers dealing with their dissatisfaction towards persons, products and organizations, they would most likely prefer to avoid any confrontation (Grougiou \& Pettigrew, 2009). If they do decide to complain, they would respond using public actions (Ngai, Heung, \& Chan, 2007). However, a separate study has found a positive relation between age and complaining behaviour (Metehan \& Yasemin, 2011). Since consumers over the age of 40 expect more from their purchased products, they are more persuaded to complain when they experience dissatisfaction. Given the implication of generation and the contradicting findings in past literature, it necessitates the present study to look into CCB by generations in the Malaysian context.

A generation is defined as a group of individuals who are born during the same time period and who experience similar external events during their late adolescent and early adulthood years (Meredith \& Schewe, 1994; Rogler, 2002; Ryder, 1965). As such it goes beyond what age alone can explain because it explores the life journey of individuals through their formative years (Motta \& Schewe, 2008; Smola \& Sutton, 2002). Although different 
generations might share some similarities, cross-sectional studies have provided support to fundamental differences between any two generations that go beyond the demographics of age and life-stage (Loroz \& Helgeson, 2013; Twenge, Campbell, Hoffman, \& Lance, 2010). Therefore, it can be said that CCB between two generations can neither be entirely similar nor different. This gives rise to the need to look into complaint behaviour by generations in the present study.

\subsection{Theoretical Grounding on Complaint Behaviour}

There are theories of complaint behaviour which explain the actions taken by consumers in order to express their dissatisfactions. Originally, Hirschman's theory of exit, voice and loyalty is used to explain a person's dissatisfaction towards relations, organizations and employment. It is also used to describe complaint process between the buyers and the retailers (Maute \& Forrester, 1992). The theory proposes exit, voice and loyalty as potential responses towards the dissatisfaction and it is later found to be useful in categorizing CCB (Boutaibi, 2014; Kruger \& Mostert, 2014). It also highlights the fact that although the loyal consumers are not motivated to respond negatively due to dissatisfaction, this does not mean that they maintain positive feelings towards the organizations and products (Maute \& Forrester, 1992; Bolton \& Bronkhorst, 1995). However, it tends to only observe the visible behavioural responses, like switching and making obvious complaints (Hee, 2007).

Another theory pertaining to CCB that is widely accepted is the Day and Landon's taxonomy of consumer complaint behaviour (Broadbridge \& Marshall, 1995). There are three choices available for consumers who are dissatisfied with the purchase, namely no action, private action and public action. The first decision the consumers have to make is to decide whether to take some form of action or none. If an action is decided, the consumers would then consider taking either private action or public action. Such decision process explains the nature and the importance of action based on the dissatisfaction level of the product and the valuation of effort required and expected to perform such action. The theory not only elucidates the options that dissatisfied consumers can have, it also explains some of the factors which might affect the eventual decisions (Day \& Landon, 1976).

Singh's taxonomy of consumer complaint responses is another theory on the subject matter (1988). He developed the three-dimensional typology that differentiates numerous consumers' complaint behaviours based on the object that the response is directed. The voice response is a behaviour directed towards the objects, such as seeking redress from the organization. The private response, in turn, is a behaviour directed towards the objects which is not directly involved in the consumers' dissatisfaction experience, such as telling their family and friends. Lastly, the third party response is a behaviour directed towards the objects which are external to the consumers, such as taking legal actions and making complaints via printed media. As such, the theory emphasizes more on the objects of CCB responses than the consumers' actual complaint behaviour (Maute \& Forrester, 1992).

Theory of cognitive dissonance is often used to explain how dissatisfaction would lead to high dissonance and the subsequent actions to eliminate it (Thomas, 2010). It elucidates a state of imbalance between one's cognition that results from the contradictory messages, objects, events or experiences (Awa \& Nwuche, 2010). In marketing literature, it happens when the products purchased and used do not meet the expectations (Salzberger \& Koller, 2010). The theory also suggests that high dissonance becomes a driving factor which causes the consumers to take some form of action to eliminate the state of discomfort, one of them being making complaint. Suffice to say that CCB cannot be taken lightly. If it is unaddressed appropriately, it could have serious repercussion for the organizations and businesses.

\subsection{Theoretical Grounding on Generational Transmission}

To date there is no concrete theory which systematically explains the mechanism of transmission among generations. There are, however, studies on parents and children's behaviour by using the social learning theory. It is asserted that children learn behaviour from interactions with important people in their environment, and most of the time these people are their parents (Scott, Doolan, Beckett, Harry, \& Cartwright, 2010). It is found that demonstration and reinforcement play important roles in shaping their behaviour. Another recent study, which looks into value similarities among grandparents, parents, and adolescent children, concludes that parent-adolescent value similarity is lower than grandmother-parent similarity (Barni, Ranieri, \& Scabini, 2012). It also highlights the strong interaction between family and social-cultural context in value choices and in determining the level of similarity among family members. Moreover, daughters are found to be more similar to their parents than are sons (Barni \& Ranieri, 2010; Whitbeck \& Gecas, 1988). This provides the basis to the present study to delve into the similarities and differences of complaint behaviour between two generations, specifically the mothers and the daughters. Given the fact that past studies have shown inconclusive results on 
CCB by older and younger generations, it is imperative to scrutinize the subject matter with interpretative inquiry to explain the phenomenon under investigation.

\section{Research Methodology}

\subsection{Research Design}

Qualitative approach was used to explore and understand CCB by generations and transmission of complaint behaviour between two generations. Qualitative method is deemed more suited because it provides avenues to elicit consumer's account of thoughts and actions (Badghish, Stanton, \& Hu, 2015). Hence, purposive sampling technique was adopted to sample the respondents of two generations (Sekaran \& Bougie, 2013). Not only must the respondents be from two different generations, they must also be of mother-daughter relationship, where the daughter is at her young adulthood (Rogler, 2002). It is because mothers are most likely the persons who purchase products for the families and daughters the ones who accompany. Since there is no specific rule to determine sample size in qualitative research (Perry, 1998), past studies were referred to so as to predetermine the number of mothers and daughters needed to generate findings which carry practical meaningfulness to the purpose of the study (Patton, 1990). Subsequently, a minimum of four cases was determined (Miles \& Huberman, 1994). Consensus panel, a type of group interview, was selected as data collection method as it helped identify group decisions or unitary response to specific questions (Coreil, 1995; Fink et al., 1984). Specifically, dyad interview was utilized as it involved the data that span two individuals in the same family. As such, the combination of the mother and the daughter was regarded as one unit of measurement in the study.

Both the mothers and the daughters were asked to recall a negative event during the past 3 months because such event would likely have an adverse effect on their attitude and behaviour towards the persons who facilitated the purchasing process, the organizations and the products (Tronvoll, 2008). In addition, they were also asked to comment about the complaint behaviour of each other. All dyad interviews were conducted at respondents' houses to ensure they were comfortable with the environment and the interview (Rubin \& Rubin, 2005). Subsequently, dyadic and content analysis was used to examine the responses, and the similarities and differences of both respondents (Gonzalez \& Griffin, 2012). All interviews were recorded and transcribed, and the transcripts were checked by an independent person to match against the recorded interview (Kurasaki, 2000). Data analysis was carried out by multiple coders to secure inter-coder reliability (Hruchka et al., 2004).

\section{Findings and Discussions}

\subsection{Complaint Behaviours by Generations}

Five consensus panel discussions using dyad interview are carried out. Table 1 shows the themes and the selected quotes related to complaint behaviours of the first pair of mother and daughter. While both the mother and the daughter tend to seek redress from the seller in person directly, the latter is likely to make complaint using electronic media such as E-mail and Facebook. Moreover, the daughter tends to seek redress directly if the product is of value and if immediate action is necessary.

Table 1. Themes and quotes of the first pair

\begin{tabular}{|c|c|}
\hline Mother & Daughter \\
\hline $\begin{array}{l}\text { Seek redress from the seller in person directly } \\
\text { That time after I bought a pack of rice back home, the rice smelled } \\
\text { weird and tasted sour after I cooked. I went back to the shop and } \\
\text { told the owner about it. At the end, the owner changed a new pack } \\
\text { of rice for me. }\end{array}$ & $\begin{array}{l}\text { Seek redress from the seller in person directly } \\
\text { Because I think that face-to-face explanation of the whole incident } \\
\text { to the person in-charge will be better, we are able to communicate } \\
\text { well, they are able to understand clearly and they can help to solve } \\
\text { the problems immediately. } \\
\text { Make complaint using electronic media } \\
\text { Because my house to the Pizza Hut outlet is quite a distance and I } \\
\text { would have wasted my time to go there, so I used email. I took } \\
\text { photo of the food and attached it in my email. I also explained the } \\
\text { time it happened and the location of the outlet. } \\
\text { I will post on my own Facebook wall so that my friends know that I } \\
\text { have experienced dissatisfaction at the store. Mostly they will } \\
\text { comment and ask. Then I will respond and explain to them what has } \\
\text { actually happened so that my other friends can also know about it. }\end{array}$ \\
\hline
\end{tabular}


Table 2 presents the findings of the second pair. Similar to the previous findings, the mother will likely seek redress from the seller in person directly as she believes things can be resolved that way, such as changing the product or getting the refund. The responses from the daughter, however, suggest that while she is comfortable with complaining using electronic media, she is uncomfortable with direct confrontation in the public area. Moreover, complaining on social networking sites, such as Facebook, is not only about making the organization aware of her displeasure, it is also about publicizing it so that their friends and others would know about it.

Table 2. Themes and quotes of the second pair

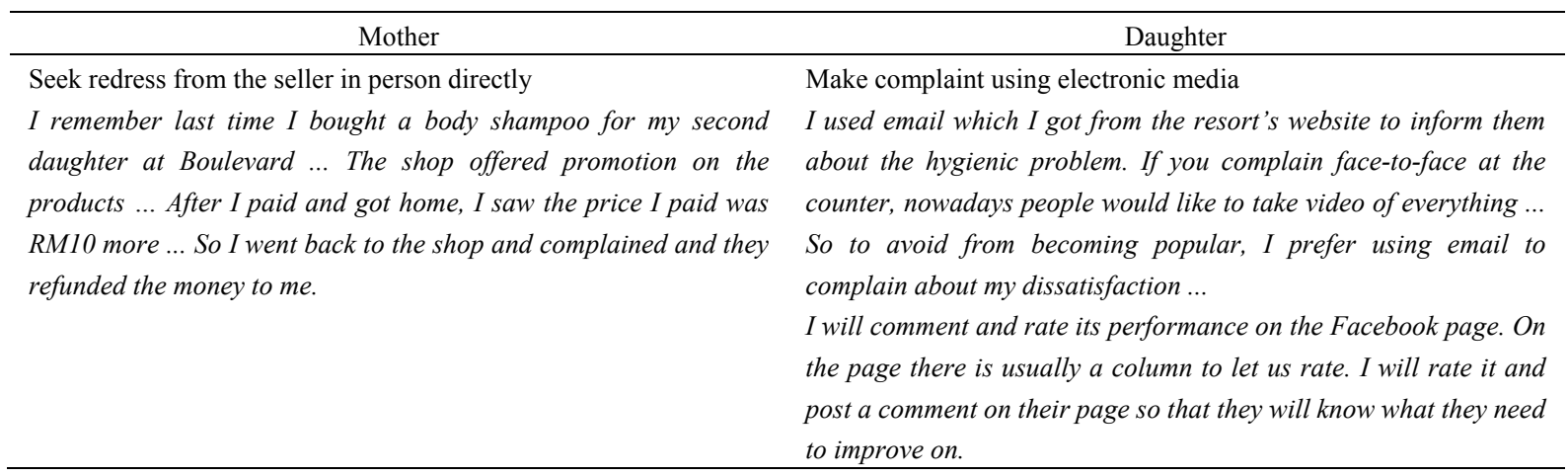

The findings as shown in Table 3 correspond to the findings of the first pair as both the mother and the daughter would seek redress from the seller in person. While the daughter would also voice out her displeasure through electronic media, the mother would complain to others verbally to make it known. Understandably, since the daughter is in her early $20 \mathrm{~s}$, she is more technology-savvy than her mother. If the problem persists, the mother would likely boycott the organization or the product altogether.

Table 3. Themes and quotes of the third pair

\begin{tabular}{|c|c|}
\hline Mother & Daughter \\
\hline Seek redress from the seller in person directly & Seek redress from the seller in person directly \\
\hline After I noticed the chocolates and peanuts had expired, I went back & After I purchased and reached home, when I opened up and used it, \\
\hline to the supermarket to ask for refund, but the staff told me ... she was & Inoticed the snow spray was waterish... So I went back to the shop \\
\hline only a staff and did not have the authority to make decisions. I went & and explained to the staff that this was not the spray as stated on it ... \\
\hline to see the manager ... He told me that he could not refund the money & the manager came out and apologized. He allowed me to exchange \\
\hline but allowed me to exchange them with different products which had & with another product with the same price. \\
\hline the same price. & Make complaint using electronic media \\
\hline Complain to others verbally & I ordered a product online, the owner told me that the thing should \\
\hline I will go home and tell others when I am displeased with & arrive within two weeks times... But after two weeks I still did not \\
\hline something ... When I find it costs too much, I will make it known to & received anything, so I emailed the owner and told her that she did \\
\hline others. & not keep her promise as I did not receive it after two months... the \\
\hline Boycott the organization or product & owner did reply my email ... and later refunded all the money ... but \\
\hline I went to the coffee shop again, and at that time her business was & I still got the thing that I bought. \\
\hline very good until she forgot my order ... So I reminded her. But ... she & \\
\hline replied me with a bad manner and gave excuses ... I became mad & \\
\hline and would not & \\
\hline
\end{tabular}

Interestingly, the mother and the daughter of the fourth pair agree that they would take no actions when they believe that direct confrontation would not solve the problem as shown in Table 4. Nevertheless, the mother would still complain to others verbally, boycott the organization and switch to others when she realizes there is nothing for her to lose. The daughter, in turn, would seek redress in person. When putting all these responses together, it is evident that taking some forms of action or not depends on the products and the beliefs about whether the reactions help resolve the problems. 
Table 4. Themes and quotes of the fourth pair

\begin{tabular}{|c|c|}
\hline Mother & Daughter \\
\hline Take no actions & Take no actions \\
\hline I think that the manager will not entertain me if I go and meet & I don't like to make things become worse. Also, I don't think the \\
\hline him ... So there is no point to complain before him ... & managers would want to entertain me as the workers are the ones \\
\hline Complain to others verbally & whom we are dealing with and they are paid to do their jobs. \\
\hline I just want to express my dissatisfactions. After I say it out and let & Seek redress from the seller in person directly \\
\hline my family know, I will feel better ... & Last week I bought the fruits... When I wanted to eat, I found the \\
\hline Boycott and switch & papaya was not fresh already ... So I straight away went back to \\
\hline Definitely I would not go back to the shop again because there are & the stall and talked to the owner. Fortunately the owner exchanged \\
\hline so many other choices out there ... & a new one for me ... \\
\hline
\end{tabular}

The findings in Table 5 basically repeat what has been shown in earlier findings. In addition to seeking redress directly, once again, the mother would complain to others verbally and the daughter would rant and rave through electronic media, such as E-mail and Wechat. The advancement of communication technology means that the daughter, like others of similar age, can voice out their dissatisfaction instantaneously through digital application which is installed on her mobile phone.

Table 5. Themes and quotes of the fifth pair

\begin{tabular}{ll}
\hline \multicolumn{1}{c}{ Mother } & \multicolumn{1}{c}{ Daughter } \\
\hline Seek redress from the seller in person directly & Seek redress from the seller in person directly \\
I bought the canned food from a shop. When I was at home, I & I will point out the mistake and put on an angry face so that when \\
noticed the canned food was already expired ... But I had lost the & they look at me, they will know that I am unhappy with it. \\
receipt ... I went back to the shop and let the owner see the & Make complaint using electronic media \\
products. The purpose I did this is to let him know that he had to & I will email because I can correct my grammar and the message \\
check the products carefully next time... & will be clearer ... so I prefer to write .. .I am a bad tempered \\
Complain to others verbally & person. So if I experience dissatisfaction, I will post on Wechat \\
I won't go back and complain but I will talk to my family & moments mostly to express my anger ... Mostly my friend will \\
members... Talk to them to let them know so that they will be & Wechat me if they see my post, then I will tell them what has \\
careful with it next time... & happened to let them know ... \\
\hline
\end{tabular}

The overall findings seem to suggest that the older generation, the mothers, tends to seek redress directly if they believe such action would bring in favourable outcome. They would also complain to others verbally to voice out their displeasure and warn them about it. If they complain but the problem persists, they would likely boycott the organization and switch to other options. The younger generation, the daughters, is more inclined to making complaint through electronic media, especially social networking sites though they would also seek redress directly. However, they appear to be equally keen to let her friends know about the incident and comment about it to demonstrate their displeasure about something. Generally speaking, it can be concluded that the complaint behaviour by the mothers and the daughters are neither wholly identical nor different. Such phenomenon infers both the transmission of behavioural values from the mothers to the daughters and the shaping of behaviours of the daughters due to the socio-cultural context. Apparently, when the mothers have the propensity to seek redress directly, the daughters tend to respond in similar fashion. Moreover, if the mothers always shy away from direct confrontation, the daughters would do the same. While the mothers might choose to tell others about it verbally, the daughters find social networking sites as avenues to rant on. Hence, transmission of behavioural values pertaining to complaint does take place between the mothers and the daughters when they are dissatisfied with certain products. Nevertheless, the use of electronic media is not something the daughters inherit from their mothers, suggesting that they learn and adopt it from the social context that they are living in. The aforementioned thus underscores both the presence of generational gaps (differences) and generational transmission in complaint behaviour and how such behaviour can be partially transmitted from the older generation to the younger generation.

\section{Implications and Conclusion}

It is imperative to realize many of the purchase decisions and purchase activities are still carried out jointly with family members. Consequently, when a product does not meet expectations, dissatisfaction and some forms of 
complaint are bound to happen, and the accompanying members would be most likely affected. As shown in the findings, complaint behaviour is not entirely similar across generations. While it is necessary for managers, marketers and business personnel to handle the direct complaint in an amicable manner to avoid the spread of negative word-of-mouth from the older generation, it is also pivotal to resolve the displeasure of the younger generation so as to prevent its spread through electronic word-of-mouth and subsequently backlash from social groups. However, generational transmission or learning of complaint behaviour is a more intricate matter. Unintended effects, and hence unintended consequences, are something which businesses need to be mindful of as the older generation can pass on their displeasure about the persons, organizations and products to the younger generation. If the mothers continue to complain about certain things to their daughters, it would be natural and spontaneous for them to pick it up and make it known in their online social groups. Noticeably, Malaysia is emerging as a promising and prospective business market, and the lack of understanding about CCB by generations could be detrimental to business performance and sustainability. Given the complexity and dynamism of the contemporary business environment, knowing how to satisfy consumers and how to resolve dissatisfaction by generations could prove to be pivotal to remaining competitive and being successful.

Due to the explorative nature of the research, the present study is delimited to just five pairs of mothers and daughters in Malaysia. As such, differences in terms of ethnicity, geographical location, family size and lifestyles are not taken into consideration. Besides, the study is also delimited to a specific behaviour. Hence, more investigations are needed to deepen and broaden the scope by looking into various behaviours across multiple generations. Ultimately, it is hopeful that a framework of generational transmission be developed to articulate the relationships of demographic and behavioural components and facilitate any future studies on the subject matter to provide a more comprehensive explanation to consumer behaviour by generations.

\section{Acknowledgements}

This study was presented at International Borneo Business Conference (IBBC) at Universiti Malaysia Sabah, Kota Kinabalu on 7-8 September. The paper was revised for publication purpose. The authors acknowledge the financial support from Universiti Malaysia Sarawak under Fundamental Research Grant Scheme (Grant no: FRGS/2/2013/SS05/UNIMAS/01/1). The authors wish to express their gratitude to Ministry of Higher Education (MOHE) and UNIMAS for supporting the research carried out.

\section{References}

Awa, H. O., \& Nwuche, C. A. (2010). Cognitive consistency in purchase behaviour: Theoretical \& empirical $\begin{array}{lllll}\text { analyses. International Journal of Psychological Studies, 2(1), 44-54. } & \text {. }\end{array}$ http://dx.doi.org/10.5539/ijps.v2n1p44

Badghish, S., Stanton, J., \& Hu, J. (2015). An exploratory study of customer complaint behaviour (CCB) in Saudi Arabia. Asian Journal of Business Research, 50-68.

Bandura, A. (1971). Social Learning Theory. New York, NY: General Learning Press.

Barni, D., \& Ranieri, S. (2010). La trasmissioned eivalori in famiglia: Una misura diadica della similarità tra genitori e figli. In C. Galimberti \& G. Scaratti (Eds.), Epistemologie della complessità nella ricerca psicologica (pp. 63-96). Milano: Vita e Pensiero.

Barni, D., Ranieri, S., \& Scabini, E. (2012). Value similarity among grandparents, parents, and adolescent children: Unique or stereotypical? Family Science, 3(1), 46-54.

Barni, D., Ranieri, S., Scabini, E., \& Rosnati, R. (2011). Value transmission in the family: Do adolescents accept the values their parents want to transmit? Journal of Moral Education, 40(1), 105-121.http://dx.doi.org/10.1080/03057240.2011.553797

Bolton, R. N., \& Bronkhorst, T. M. (1995). The relationship between customer complaints to the firm and subsequent exit behavior. Advances in Consumer Research, 22, 94-100.

Boutaïbi, L. S. (2014). What determines consumers' complaint behavior after purchasing an inappropriate or defective financial retail product? (Unpublished master thesis). Erasmus Universiteit Rotterdam, Netherlands.

Broadbridge, A., \& Marshall, J. (1995). Consumer complaint behaviour: The case of electrical goods. International Journal of Retail \& Distribution Management, 23(9), 8-18. http://dx.doi.org/10.1108/09590559510098663.

Carnoy, D. (2015). Guess what's the lowest rated Apple product in Apple's online store? Retrieved from http://www.cnet.com/news/these-are-the-lowest-rated-products-in-apples-online-store/ 
Cipriani, M., Giuliano, P., \& Jeanne, O. (2007). Like mother like son? Experimental evidence on the transmission of values from parents to children. Discussion Paper No. 2768. Bonn: Germany.

Coreil, J. (1995). Group interview methods in community health research. Medical Anthropology, 16, 193-210.

Day, R. L., \& Landon, E. L. (1976). Collecting comprehensive consumer complaint data by survey research. Advances in Consumer Research, 3(1), 263-268.

De Run, E. C., \& Ting, H. (2013). Generational cohorts and their attitudes toward advertising. Trziste/Market Journal, 25(2), 143-160.

Fink, A., Kosecoff, J., Chassin, M., \& Brook, R. H. (1984). Consensus methods: Characteristics and guidelines for use. American Journal of Public Health, 74(9), 979-983.

Gonzalez, R., \& Griffin, D. (2012). Dyadic data analysis. In H. Cooper (Ed.), APA Handbook of Research Methods in Psychology (pp. 439-450). Data Analysis and Research Publication.

Grougiou, V., \& Pettigrew, S. (2009). Seniors' attitudes to voicing complaints: A qualitative study. Journal of Marketing Management, 25(9-10), 987-1001. http://dx.doi.org/10.1362/026725709X479336

Hee, J. R. (2007). A typology of consumer dissatisfaction responses: Exit, voice, loyalty, and "more". (Unpublished doctoral dissertation). The Pennsylvania State University, US.

Hoge, D. R., Petrillo, G. H., \& Smith, E. I. (1982). Transmission of religious and social values from parents to teenage children. Journal of Marriage and Family, 44(3), 569-580. http://dx.doi.org/10.2307/351580

Hofstede, G., \& Bond, M. H. (1988). The Confucius connection: From cultural roots to economic growth. Spring, 16(4), 5-21.

Hruschka, D. J., Schwartz, D., St. John, D. C., Picone-Decaro, E., Jenkins, R. A., \& Carey, J. W. (2004). Reliability in coding open-ended data: Lessons learned from HIV behavioural research. Field Methods, 16(3), 307-331.

Kang, J., Zhang, X., \& Zheng, Z. H. (2009). The relationship of customer complaints, satisfaction and loyalty: Evidence from China's mobile phone industry. China-USA Business Review, 8(12), 22-36.

Kim, C. M., Kim, S. H., Im, S., \& Shin, C. H. (2003). The effect of attitude and perception on consumer complaint intentions. Journal of Consumer Marketing, 20(4), 352-371. http://dx.doi.org/10.1108/07363760310483702

Kruger, L., \& Mostert, P. G. (2014). The influence of relationship intention on cell phone users' attitudes towards complaining and complaint behaviour. Southern African Business Review, 18, 35-63.

Kurasaki, K. S (2000). Intercoder reliability for validating conclusions drawn from open-ended interview data. Field Methods, 12(3), 179-194.

Loroz, P. S., \& Helgeson, J. G. (2013). Boomers and Their Babies: An Exploratory Study Comparing Psychological Profiles and Advertising Appeal Effectivenss across Two Generations. Journal of Marketing Theory and Practice, 21(3), 289-306.

Mahayudin, N. H. M., Haron, S. A., \& Chan, B. Y. F. (2010). Unpleasant market experience and consumer complaint behavior. Asian Social Science, 6(5), 63-69.

Malhotra, N. K., Oly-Ndubisi, N., \& Agarwal, J. (2008). Public versus private complaint behaviour and customer defection in Malaysia: Appraising the role of moderating factors. Esic Market, 131, 27-59.

Mat, A., Said, A. M., Bakar, E. A., Munir, Z. A., \& Kori, N. L. (2014). Determining the educational background differences in complaint behavior among automobile repairs and service consumers in Shah Alam. Proceedings of the $2^{\text {nd }}$ ASEAN Entrepreneurship Conference. Penang, Malaysia: Shangri-La Rasa Sayang Resort.

Maute, M. F., \& Forrester, W. R. (1992). The structure and determinants of consumer complaint intentions and behavior. Journal of Economic Psychology, 14, 219-247. http://dx.doi.org/10.1016/0167-4870 (93)90001-2

Mellor, D. J., Martin, J., \& Bradley, A. (2014). My expectations from raising concerns and complaint. Retrieved June 15, 2016, from http://www.ombudsman.org.uk/_data/assets/pdf_file/0007/28816/Vision_report.pdf

Meredith, G., \& Schewe, C. D. (1994). The Power of Cohorts. American Demographics, 16(12), 22-28.

Metehan, T., \& Yasemin, Z. A. (2011). Demographic characteristics and complaint behavior: An empirical study concerning Turkish customers. International Journal of Business and Social Science, 2(9), 42-48. 
Miles, M., \& Huberman, A. M. (1994). Qualitative Data Analysis: An Expanded Sourcebook (2nd ed.). Thousand Oaks, CA: Sage.

Motta, P. C., \& Schewe, C. (2008). Are Marketing Management Decisions Shaped during One's Coming of Age? Management Decision, 46(7), 1096-1110. http://dx.doi.org/10.1108/00251740810890249

Ndubis, O. Y., \& Tam, Y. L. (2007). Evaluating gender differences in the complaint behavior of Malaysian consumers. Asian Academy of Management Journal, 12(2), 1-13.

Ngai, E. W. T., Heung, V. C. S., Wong, Y. H., \& Chan, F. K. Y. (2007). Consumer complaint behaviour of Asians and non-Asians about hotel services an empirical analysis. European Journal of Marketing, 41(11/12), 1375-1391.

Nimako, S. G., \& Mensah, A. F. (2012). Motivation for customer complaining and non-complaining behaviour towards mobile telecommunication services. Asian Journal of Business Management, 4(3), 310-320.

Patton, M. Q. (1990). Qualitative Evaluation and Research Methods (2nd ed.). Newbury Park, CA: Sage Publications.

Perry, C. (1998). Processes of a case study methodology for postgraduate research in marketing. European Journal of Marketing, 32(9), 785-802.http://dx.doi.org/10.1108/03090569810232237

Rubin, H. J., \& Rubin, I. S. (2005). Qualitative interviewing: The art of hearing data (2nd ed.). New York, NY: Sage Publications.

Rogler, L. H. (2002). Historical generations and psychology: The case of the Great Depression and World War II. American Psychologist, 57(12), 1013.

Ryder, N. B. (1965). The Cohort as a Concept in the Study of Social Change. American Sociological Review, 30, 843-861.

Salzberger, T., \& Koller, M. (2010). Investigating the impact of cognitive dissonance and customer satisfaction on loyalty and complaint behaviour. Revista Brasileira de Marketing, 9(1), 5-16.

Scott, S., Doolan, M., Beckett, C., Harry, S., \& Cartwright, S. (2010). Preliminary findings from the helping children achieve study. Research Report DFE-RR 185am, Department for Education, UK.

Sekaran, U., \& Bougie, R. (2013). Research methods for business: A skill building approach paperback (6th ed.). West Sussex, UK: John Wiley \& Sons.

Singelis, T. M., \& Sharkey, W. F. (1995). Culture, self-construal, and embarrass ability. Journal of cross-cultural psychology, 26(6), 622-644. http://dx.doi.org/10.1177/002202219502600607

Singh, J. (1988). Consumer complaint intentions and behavior: Definitional and taxonomical issues. Journal of Marketing, 52(1), 93-107.

Singh, R. (2015). So is it Maggi Mee or Maggot Mee? Retrieved from http://www.therakyatpost.com/viral/2015/03/02/so-is-it-maggi-mee-or-maggot-mee-video/

Smola, K. W., \& Sutton, C. D. (2002). Generational Differences: Revisiting Generational Work Values for the New Millennium. Journal of Organizational Behavior, 23, 363-382. http://dx.doi.org/10.1002/job.147

Thomas. J. B. (2010). The social psychology of IT security auditing from the auditee's vantage point: Avoiding cognitive dissonance. Isaca Journal, 3, 1-4.

Tronvoll, B. (2008). Customer Complaint Behaviour in Service (Unpublished doctoral dissertation). Karlstad University Studies, Karlstad, Sweden.

Tronvoll, B. (2011). Negative emotions and their effect on customer complaint behaviour. Journal of Service Management, 22(1), 111-134.

Twenge, J. M., Campbell, S. M., Hoffman, B. J., \& Lance, C. E. (2010). Generational Differences in Work Values: Leisure and Extrinsic Values Increasing, Social and Intrinsic Values Decreasing. Journal of Management, 39, 1117-1142. http://dx.doi.org/10.1177/0149206309352246

Vincent, N. A., \& Webster, C. M. (2005). Emotions and response actions in consumer complaint behaviour. ANZMAC Conference: Consumer Behaviour (pp. 352-358).

Whitbeck, L. B., \& Gecas, V. (1988). Value attributions and value transmission between parents and children. Journal of Marriage and Family, 50, 829-840. 


\section{Copyrights}

Copyright for this articles retained by the author(s), with first publication rights granted to the journal.

This is an open-access article distributed under the terms and conditions of the Creative Commons Attribution license (http://creativecommons.org/licenses/by/4.0/). 